\title{
Studies on the bioremediation capacity of the adult black clam, Chione fluctifraga, of shrimp culture effluents
}

Estudios de la capacidad de biorremediación de efluentes de camarón de la almeja negra adulta, Chione fluctifraga

\section{Luis R. Martínez-Córdova ${ }^{1 *}$, José A. López-Elías', Marcel Martínez-Porchas², Tamara Bernal-Jaspeado ${ }^{1,4}$ and Anselmo Miranda-Baeza ${ }^{3}$}

\author{
${ }^{1}$ DICTUS, Universidad de Sonora, Blvd. Luis Donaldo Colosio, S/N, Hermosillo, Sonora, 83000, México. lmtz@guaymas.uson.mx \\ ${ }^{2}$ Centro de Investigación en Alimentación y Desarrollo, A.C., Carretera a la Victoria Km 0.6, Hermosillo, Sonora 83304, México \\ ${ }^{3}$ CESUES, Navojoa, Sonora, México \\ ${ }^{4}$ Universidad Autónoma de Nayarit, Tepic, Nayarit, México
}

\begin{abstract}
Resumen.- La almeja negra, Chione fluctifraga, puede ser utilizada para biorremediar efluentes de descarga en cultivos de camarón. Con este propósito se evaluó durante 77 días, el efecto de dos densidades de almeja ( 12,5 y 25 especímenes $\left.\mathrm{m}^{-2}\right)$ y un control $\left(0 \mathrm{~m}^{-2}\right)$ sobre la calidad de agua de efluentes crudos de un cultivo semi-intensivo de camarón (Litopenaeus vannamei; $25 \mathrm{~m}^{-2}$ ). Parámetros tales como, sólidos suspendidos totales (TSS), sólidos orgánicos suspendidos (OSS), nitrógeno amoniacal total (TAN) y nitrógeno total (TN) fueron medidos en los efluentes crudos, control, tratamientos y agua del estuario (fuente de agua para el cultivo de camarón). Los TSS y OSS disminuyeron en el control y los tratamientos en comparación con los efluentes sin tratar. Los TSS y OSS disminuyeron durante los primeros 22 días, sin registrar diferencias entre control y tratamientos. Sin embargo, los tratamientos tuvieron una mayor disminución en los niveles de TSS y OSS a los 48 y 77 días de cultivo, en comparación con el control. Los niveles de TAN registraron los valores más baj os en ambos tratamientos, seguidos por el control y los efluentes de camarón; no se observaron diferencias significativas para el TN. Los resultados indican que Chione fluctifraga tiene capacidad como biorremediador y puede sobrevivir en efluentes de estanques de camarón.
\end{abstract}

Palabras clave: Biofiltración, agua de descarga, contaminación ambiental, cultivo de camarón, calidad de agua

\begin{abstract}
The black clam, Chione fluctifraga, can be used to bioremediate discharge effluents produced by shrimp aquaculture. With such purpose we evaluated during 77 days, the effect of two densities of clams ( 12.5 and 25. specimens $\mathrm{m}^{-2}$ ) and a control $\left(0 \cdot \mathrm{m}^{-2}\right)$ on the water quality of raw effluents from a semi-intensive culture of shrimp (Litopenaeus vannamei; $25 \mathrm{~m}^{-2}$ ). Parameters such as total suspended solids (TSS), organic suspended solids (OSS), total ammonium nitrogen (TAN) and total nitrogen (TN) were measured in raw effluents, control, treatments and estuary (water source for shrimp culture). The TSS and OSS diminished in control and treatments, compared with untreated effluents. The TSS and OSS decreased over time with no significant difference observed among the treatments during the first 22 days of trial. However, treatments had a greater decrease of TSS and OSS levels at days 48 and 77 compared with the control. TAN recorded the lowest levels in both treatments, followed by control and effluents respectively; no significant differences were observed for TN. The results indicate that Chione fluctifraga has ability as biorremediator and it does survive well in shrimp pond effluents.
\end{abstract}

Key words: Biofiltration, discharge water, environmental pollution, shrimp aquaculture, water quality

\section{INTRODUCTION}

Aquaculture has been one of the fastest growing industries worldwide, with total world production of around 67 million tonnes in 2006 (FAO 2008). This continuous growth has generated competition with other users of land and water and also has caused negative impacts on the effluentreceiving ecosystems (Páez-Osuna 2001a, Rahman et al. 2002, Piedrahita 2003, Primavera 2006, Sarà 2007). Some of the observed impacts have been the eutrophication and nutrification of estuaries (Páez-Osuna 2001b, JiménezCasalduero 2001, Sousa et al. 2006), destruction of mangrove forests (Thu \& Populus 2007) and pollution of water bodies (Páez-Osuna 2001b). It has been argued that aquaculture wastes, like total suspended solids (TSS) and organic suspended solids (OSS), have a negative impact on 
the environment, causing ecological imbalances (MartínezCórdova et al. 2009).

The potential negative impacts of aquaculture effluents creates a need to implement sustainable strategies such as low- or zero-water exchange, recirculation, reintegration of nutrients to the system through co-culture or polyculture practices, the use of mangrove forests as nutrient sinks (Rivera-Monroy et al. 1999, Primavera et al. 2007), and bioremediation of effluents (Troell et al. 2003). Some of these strategies are now being used in some farms for different types of culture (Neori et al. 2007).

Bioremediation can be used to reduce organic and inorganic compounds and nutrients from aquaculture effluents, mainly by the use of filter-feeding bivalves, microalgae and seaweed (Jones et al. 2002, Shpigel et al. 2005, Muangkeow et al. 2007). There are many mollusk species that have the potential to bioremediate aquatic environments, of which some of them are commerciallyimportant and could provide extra income to farmers (Rawson et al. 2002, Peharda et al. 2007). Others have been observed to reduce luminous bacteria in shrimp ponds (Tendencia 2007). It is important to evaluate the performance of these organisms as bioremediators in specific effluent waters, in order to use such natural resource to mitigate some of the contamination problems that aquaculture has caused. For instance, Yokoyama et al. (2002) studied the effect of green mussels, Perna viridis, on the water quality of a series of contiguous ponds that received shrimp pond effluents. The green mussels effectively removed excess food particles and improved water quality.

Jones \& Preston (2001) found that the shrimp effluent was an adequate environment in which bivalve mollusks thrived. Lefebvre et al. (2000) compared the nutritional value of cultured microalgae, Skeletonema costatum, and shrimp effluent as food sources for the Pacific oyster, Crassostrea gigas, not finding significant differences between both sources. Jakob et al. (1993) used shrimp-pond effluent to culture Crassostrea virginica and reported that the effluent provided all the essential nutrients required for the growth of the species.

The black clam, Chione fluctifraga, was selected for the present study because of commercial importance in Northwestern Mexico, mainly as an artisanal fishery, but it is now being farmed in the region (Tinoco-Orta \& Cáceres-Martínez 2003). The species inhabits estuaries and shallow coastal waters in the Gulf of California. It tolerates high concentrations of organic matter in the water column and can withstand a wide range of temperatures and salinities (Martínez-Córdova 1988), conditions that are similar to those prevailing in shrimp farm effluent. Large populations of $C$. fluctifraga can be found in estuaries of the region and can be easily transported to shrimp farms in close proximity to the estuary. The species has a short life cycle and can reproduce in few months (Martínez-Córdova \& MartínezPorchas 2006).

The aim of this study was to evaluate the feasibility of using adult Chione fluctifraga to bioremediate shrimp pond effluents by removing organic and inorganic suspended solids and nutrients.

\section{Materials AND Methods}

\section{EXPERIMENTAL ANIMALS}

Shrimp postlarvae (average weight $=0.3 \pm 0.05 \mathrm{~g}$ ) were obtained from a commercial hatchery (Maricultura del Pacífico, S.A.) at Bahia Kino, Sonora, México, and maintained under laboratory conditions (dissolved oxygen [DO] $6.05 \mathrm{mg} \mathrm{L}^{-1}$; fed ad libitum [Camaronina, Purina ${ }^{\circledR}$ $35 \%$ protein]; total ammonia nitrogen (TAN) was maintained at $0.01 \mathrm{mg} \mathrm{L}^{-1}$; a daily water exchange of $100 \%$ ) until shrimp reached the desired size to carry out the experiment. Clams were hand-collected from La Cruz Estuary (2848'57'’ N, $111^{\circ} 55^{\prime} 30^{\prime \prime} \mathrm{W}$ ) and maintained under the above laboratory conditions for two weeks and fed the diatom, Chaetoceros muelleri.

\section{System Configuration}

A semi-intensive shrimp culture system consisting of nine $4000 \mathrm{~L}$ plastic pools ( 4 x 2 x $0.65 \mathrm{~m}$, water depth $0.5 \mathrm{~m}$ ) was established. The pools were filled with seawater pumped from the La Cruz Estuary, which is considered both, an estuary and antiestuary (system that does not have a significant freshwater inputs; Maples et al. 1987) because it does not receive freshwater during most of the year and has high salinity levels 38 psu. The pools were provided with $0.9 \mathrm{~m}^{3}$ of sediment to achieve height of 5-6 cm. Each pool was stocked with juvenile Litopenaeus vannamei (average weight $=10 \pm 0.7 \mathrm{~g}$ ) at a density of $25 \mathrm{~m}^{-2}$. During the experiment, shrimp were fed a commercial diet (Camaronina of Purina ${ }^{\circledR}$; Hermosillo, México) containing $35 \%$ of crude protein and fed at $4 \%$ body weight $\cdot$ day $^{-1}$. The effluents discharged from the shrimp pools flowed into a plastic container and then distributed equally into nine pools (similar to those used for the shrimp culture), with a continuous flow of $16 \mathrm{~L} \mathrm{~h}^{-1}$ pool$^{-1}$ (9.6\% of daily water 
exchange). Three of the pools were stocked with clams (average size and weight $=3.5 \pm 0.3 \mathrm{~cm}$ and $17.3 \pm 4.3 \mathrm{~g}$ ) at a density of 12.5 clams $\cdot \mathrm{m}^{-2}$ (T1) and evenly distributed on the bottom of the pool. Three other pools were stocked at 25 clams $\mathrm{m}^{-2}$ (T2), and the last three remained without clams $\mathrm{m}^{-2}$ (control). These densities were based on the criterion of Miranda-Baeza et al. (2006) with the bivalve Anadara tuberculosa stocked at similar size and density.

No aeration or oxygenation was applied to any of the pools (with shrimp or clam), to avoid the re-suspension of solids.

\section{Chemical and Physical analyses}

Temperature, salinity, $\mathrm{pH}$, and dissolved oxygen concentration were recorded twice a day (0700 and 1400) in the estuary, the shrimp effluent, the control and the treatment pools using a YSI 6600 multiparameter electronic meter (YSI, Yellow Springs, OH, USA).

The total suspended solids (TSS) and the organic suspended solids (OSS) were measured on days $0,22,48$, and 77 at the same sampling points. The samples from the estuary were taken at different locations of the estuary, on a radius $3 \mathrm{~m}$ away from the water pump, at a depth of $40 \mathrm{~cm}$ from the bottom; five replicate samples were collected at every point of the estuary. Also, five replicate samples were collected per pool at every sampling date. One liter of sampled water was filtered through GFC $47 \mathrm{~mm}$ Whatman filters, which were then washed and dried at $90^{\circ} \mathrm{C}$ for $4 \mathrm{~h}$. The difference in weight between the dried filters before and after filtration was estimated as the TSS. The organic suspended solids were determined by incineration of the dried filters in a muffle at $450^{\circ} \mathrm{C}$ for $8 \mathrm{~h}$, then cooled and weighed. In order to eliminate a possible error in solids measurements, the same process was carried out with clean sea water (previously filtered and sterilized) from the Estuary, which was a basepoint subtracted for the results of TSS and OSS.

Total ammonia nitrogen was monitored at the sampling points by the salicylate method (Bower \& Holm-Hansen 1980) using a programmable spectrophotometer HACH DR4000 (Hach Co., Loveland) and the concentration of total nitrogen was measured by the persulfate digestion method following the methodology of HACH (Method 10072).

Survival was determined by the number of dead organisms in each tank at the given sampling dates. The condition index of the clams was estimated as:

$$
\left(\frac{\text { Dry body weight }}{\text { Dry shell weight }}\right) 100
$$

as suggested by De la Hoz-Aristizábal (2010).

\section{STATISTICAL ANALYSIS}

One-way ANOVA and a post-hoc Tukey test were done to analyze the results of water quality variables (temperature, salinity, dissolved oxygen, $\mathrm{pH}$ ). A repeated measures ANOVA was performed to study the results of TN, TAN. An analysis of covariance was carried out to compare the effect of time and density of clams on the levels of TSS and OSS in the treatment pools (Zar 1996).

\section{Results}

Means and ranges of temperature, salinity, dissolved oxygen, and $\mathrm{pH}$ in shrimp pools, treatments, control and the estuary did not differ between sites or treatments (Table 1).

Table 1. Means ( \pm standard deviation) of environmental variables registered in the shrimp pools, control, treatments, and estuary / Medias ( \pm desviación estándar) de las variables ambientales registradas en piscinas de camarón, control, tratamientos y estuario

\begin{tabular}{lccccc}
\hline & Shrimp pools & Control & $\begin{array}{c}\mathrm{T} 1 \\
\left(12.5 \text { clams m}^{-2}\right)\end{array}$ & $\begin{array}{c}\mathrm{T} 2 \\
\left(12.5 \text { clams m}^{-2}\right)\end{array}$ & Estuary \\
\hline Temperature $\left({ }^{\circ} \mathrm{C}\right)$ & $27.0 \pm 1.6^{\mathrm{a}}$ & $28.0 \pm 1.6^{\mathrm{a}}$ & $28.1 \pm 1.7^{\mathrm{a}}$ & $28.3 \pm 1.5^{\mathrm{a}}$ & $27.0 \pm 1.4^{\mathrm{a}}$ \\
Salinity (psu) & $40.1 \pm 0.9^{\mathrm{a}}$ & $41.0 \pm 1.1^{\mathrm{a}}$ & $41.1 \pm 0.9^{\mathrm{a}}$ & $41.0 \pm 1.0^{\mathrm{a}}$ & $40.0 \pm 0.8^{\mathrm{a}}$ \\
Dissolved oxygen $\left(\mathrm{mg} \mathrm{L}^{-1}\right)$ & $6.2 \pm 2.0^{\mathrm{a}}$ & $6.40 \pm 1.9^{\mathrm{a}}$ & $5.9 \pm 1.5^{\mathrm{a}}$ & $5.7 \pm 1.4^{\mathrm{a}}$ & $6.1 \pm 1.7^{\mathrm{a}}$ \\
pH average & $8.3^{\mathrm{a}}$ & $8.4^{\mathrm{a}}$ & $7.9^{\mathrm{a}}$ & $8.0^{\mathrm{a}}$ & $8.2^{\mathrm{a}}$ \\
pH range & $7.8-8.7$ & $8.1-8.7$ & $7.7-8.1$ & $7.9-8.2$ & $8.0-8.3$ \\
\hline
\end{tabular}

\footnotetext{
${ }^{\mathrm{a}}$ : Statistical results showing no significant differences among treatments
} 
The shrimp grew at a rate of $1 \mathrm{~g}^{\text {week }}{ }^{-1}$ during the experimental period (Fig. 1), similar to the growth rate reported in commercial farms.

The concentration of TSS increased significantly by $24 \%$ $\left(\mathrm{F}_{(4,74)}=25.8, P<0.001\right)$ and $37 \%\left(\mathrm{~F}_{(4,74)}=18.9, P<0.001\right)$ from the estuary $\left(\sim 120 \mathrm{mg} \mathrm{L}^{-1}\right)$ to the shrimp pools at days 48 and 77 respectively (Fig. 2), reaching levels above 160 $\mathrm{mg} \mathrm{L}^{-1}$.

The levels of TSS decreased over time in both, control ( 0

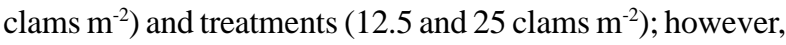
the decreasing rate was significantly higher $\left(\mathrm{F}_{(2,179)}=9.6, P\right.$ $=0.01)$ in the treatments with clams (T1 and T2) compared to the control (Fig. 3). At the end of the experiment (day 77), TSS levels of $\mathrm{T} 1$ and $\mathrm{T} 2$ were $50 \%\left(\mathrm{~F}_{(4,74)}=24.9, P<\right.$ $0.001)$ and $52 \%(P<0.001)$ respectively lower than the shrimp effluents (164 mg L $\left.{ }^{-1}\right)$, while no differences were observed between effluents and control $\left(\mathrm{F}_{(4,74)}=2.8, P=\right.$ 0.06 , Fig. 2).

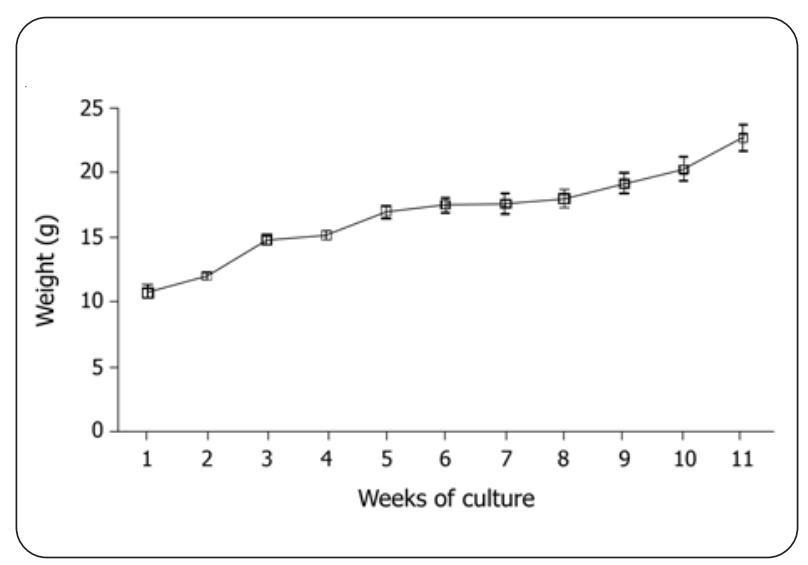

Figure 1. Individual weekly growth of Litopenaeus vannamei / Crecimiento individual semanal de Litopenaeus vannamei

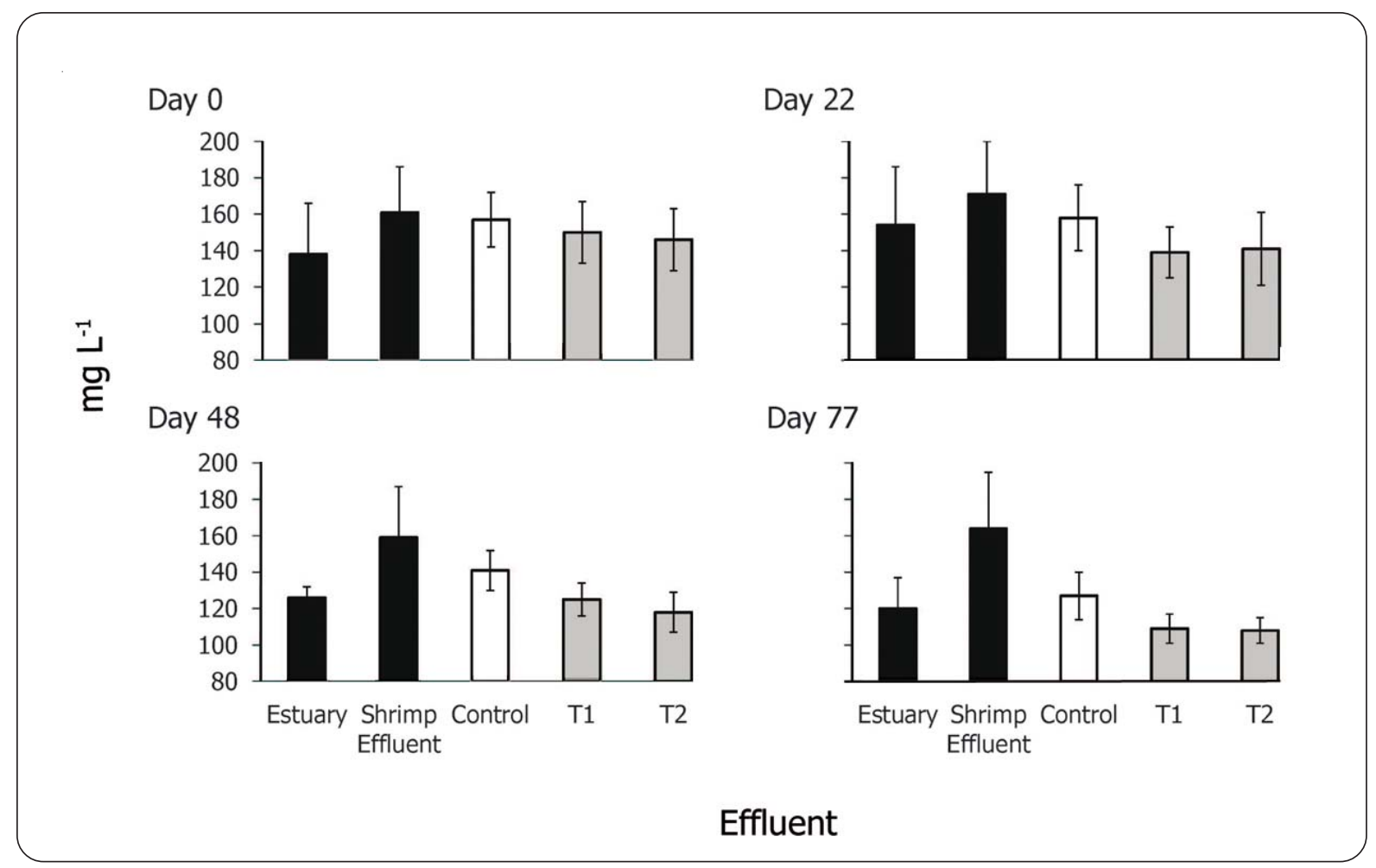

Figure 2. Total suspended solids ( $\mathrm{mg} \mathrm{L}^{-1}$ ) throughout the experimental period in the estuary, shrimp effluents, pools without

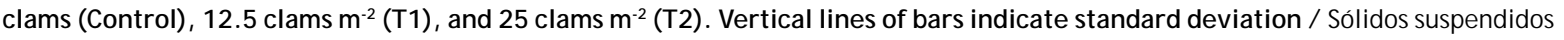
totales ( $\mathrm{mg} \mathrm{L}^{-1}$ ) a través del período experimental en el estuario, efluentes de camarón, piscinas sin almejas (Control), 12,5 almejas $\mathrm{m}^{-2}$ (T1), y 25 almejas $\mathrm{m}^{-2}$ (T2). Las líneas verticales de las barras indican la desviación estándar 


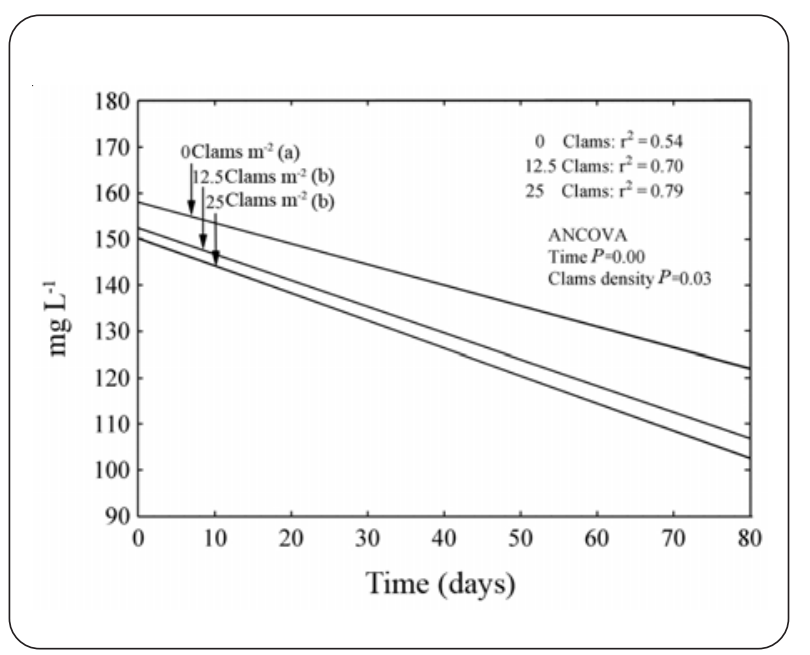

Figure 3. Analysis of the decreasing rate of total suspended solids

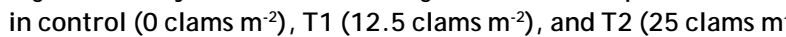
$\left.{ }^{2}\right)$ throughout the time. Different letters inside the parenthesis indicate significant differences $(\mathbf{P}<\mathbf{0 . 0 5})$ / Análisis de la tasa de disminución de sólidos suspendidos totales en el control ( 0 almejas $\left.\mathrm{m}^{-2}\right), \mathrm{T} 1$ (12,5 almej as $\left.\mathrm{m}^{-2}\right)$, y T2 (25 almej as $\left.\mathrm{m}^{-2}\right)$ a través del tiempo. Letras diferentes dentro del paréntesis indican diferencias significativas $(P<0,05)$
Organic suspended solids increased significantly in shrimp pools at days $48\left(\mathrm{~F}_{(4,74)}=98.8, P<0.001\right)$ and 77 $\left(\mathrm{F}_{(4,74)}=120.4, P<0.001\right)\left(>24 \mathrm{mg} \mathrm{L}^{-1}\right.$, Fig. 4). Similar to the TSS results, the OSS levels in treatments and control tended to decrease over time, however the lowest decreasing rate was observed in the control and the highest in T2 (Fig. $5)$. By the last day of experiment, the concentration of OSS had decreased by $27 \%, 45 \%$ and $42 \%\left(\mathrm{~F}_{(4,74)}=87,6, P<\right.$ $0,001)$ after flowing from the shrimp pools $\left(\sim 22 \mathrm{mg} \mathrm{L}^{-1}\right)$ through the control $\left(<17 \mathrm{mg} \mathrm{L}^{-1}\right)$, T1 and T2 pools $(<12 \mathrm{mg}$ $\left.\mathrm{L}^{-1}\right)$, respectively.

The TAN increased significantly in the shrimp pools ( 0.16 $\left.\mathrm{mg} \mathrm{L}^{-1}\right)$ and decreased in the control $\left(0.036 \mathrm{mg} \mathrm{L}^{-1}\right), \mathrm{T} 1(0.011$ $\left.\mathrm{mg} \mathrm{L}^{-1}\right)$ and T2 $\left(0.013 \mathrm{mg} \mathrm{L}^{-1}\right)$ pools $\left(\mathrm{F}_{(4,299)}=6,3, P=0.01\right)$, although the control pools showed a smaller decrease than the pools containing clams (T1 and T2) (Fig. 6). Despite T1 and T2 showed lower concentrations of TN (10.4 and 10.2 $\mathrm{mg} \mathrm{L}^{-1}$ ), no significant differences were observed among treatments $\left(\mathrm{F}_{(4,299)}=2.9, P=0.05\right.$; Fig. 6).

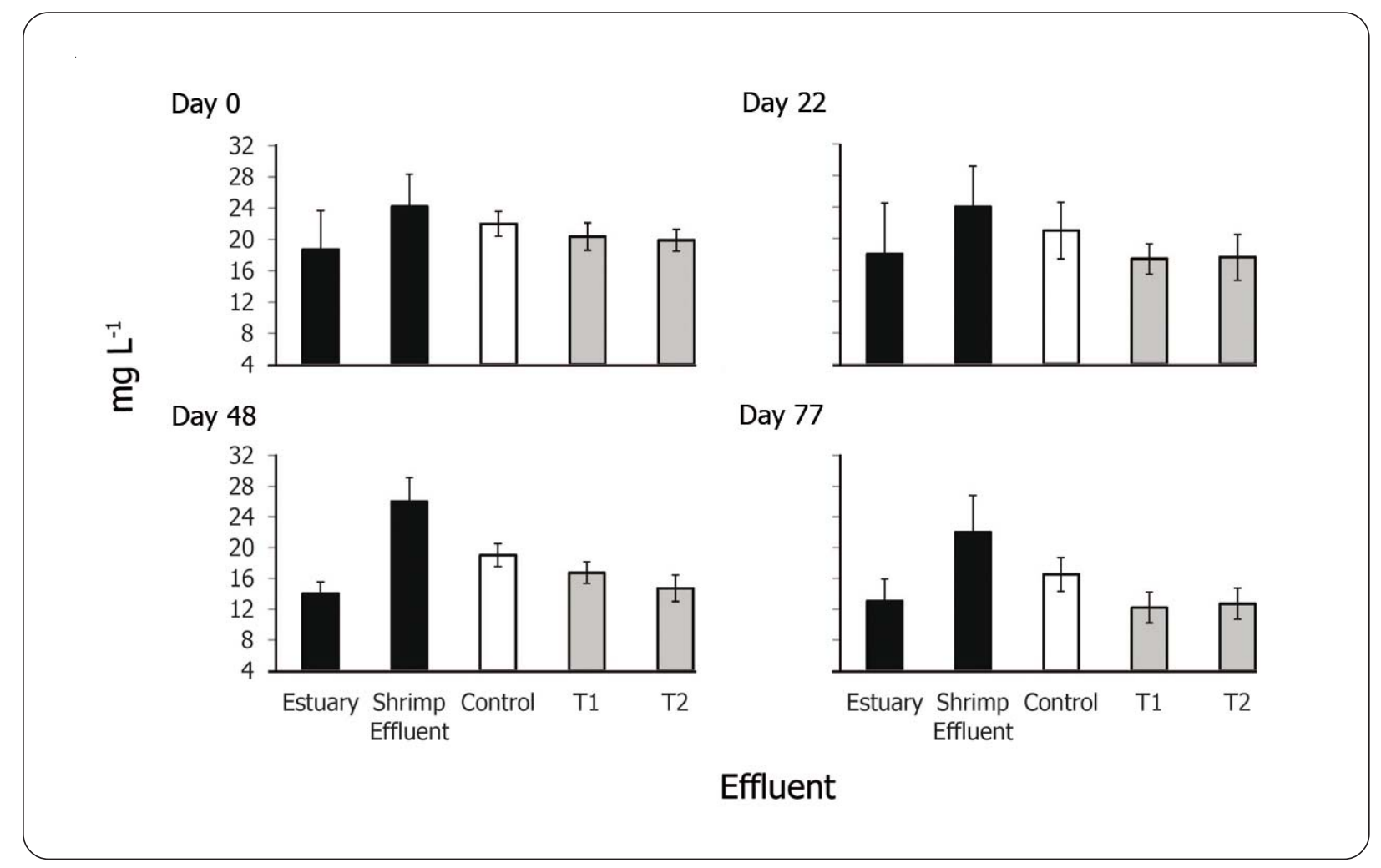

Figure 4. Organic suspended solids $\left(\mathrm{mg} \mathrm{L}^{-1}\right)$ throughout the experimental period in estuary, shrimp effluents, pools without clams (Control), 12.5 clams $\mathbf{m}^{-2}$ (T1), and 25 clams $\mathrm{m}^{-2}$ (T2) / Sólidos orgánicos suspendidos $\left(\mathrm{mg} \mathrm{L}^{-1}\right)$ a través del período experimental en el estuario, efluentes de camarón, piscinas sin almejas (Control), 12,5 almejas $\mathrm{m}^{-2}$ (T1), y 25 almejas m² (T2) 


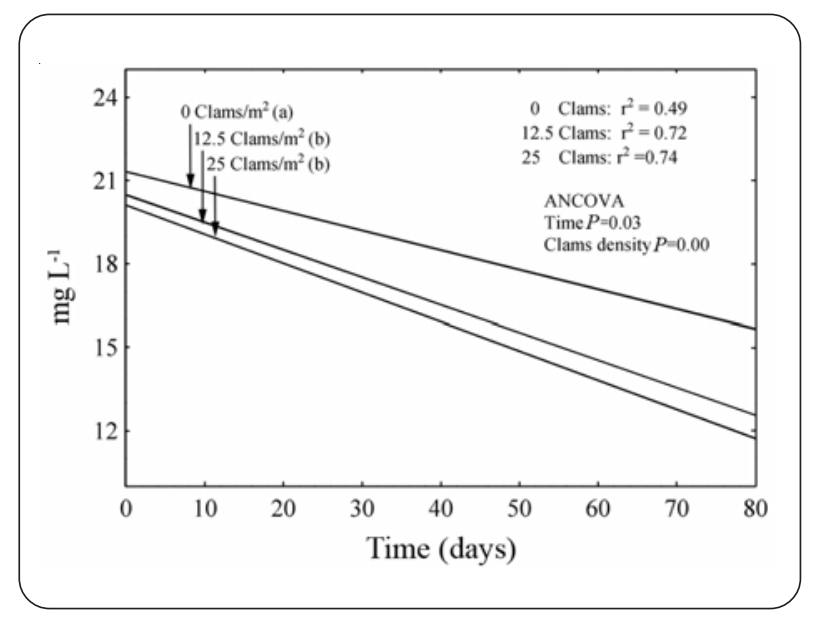

Figure 5. Analysis of the decreasing rate of total suspended solids

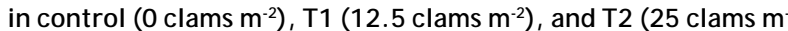
$\left.{ }^{2}\right)$ throughout the time. Different letters inside the parenthesis indicate significant differences $(\mathbf{P}<\mathbf{0 . 0 5})$ / Análisis de la tasa de disminución de sólidos orgánicos suspendidos en el control (0 almej as $\left.\mathrm{m}^{-2}\right)$, T1 (12,5 almejas $\left.\mathrm{m}^{-2}\right)$, y T2 (25 almejas $\mathrm{m}^{-2}$ ) a través del tiempo. Letras diferentes dentro de los paréntesis indican diferencias significativas $(P<0,05)$

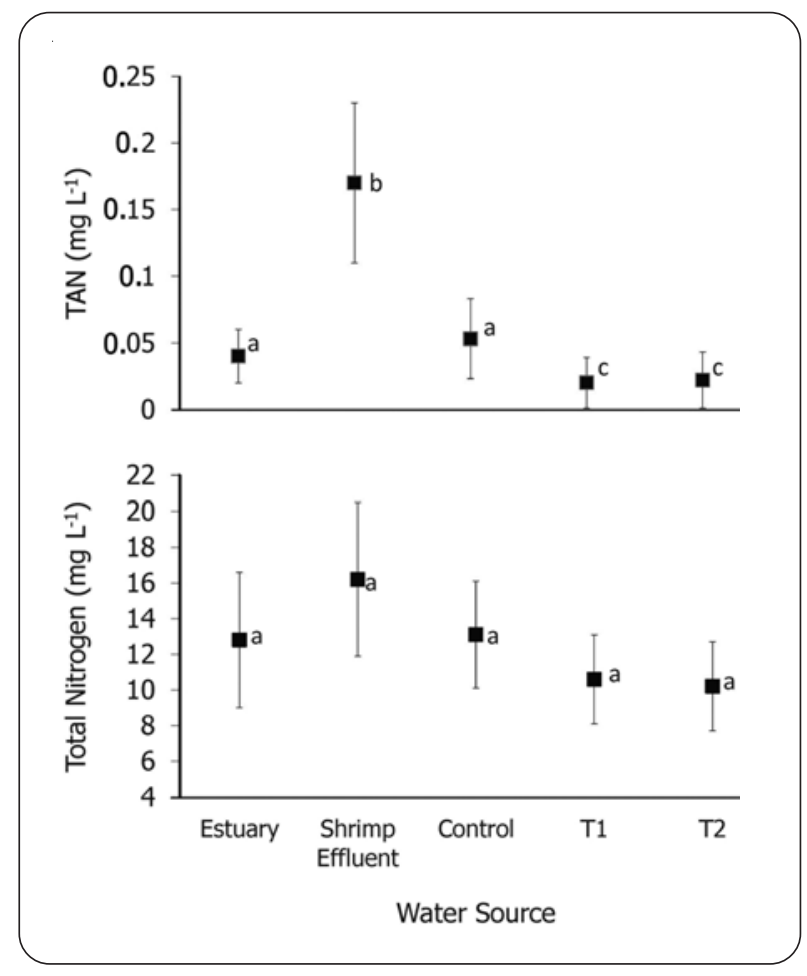

Figure 6. Total ammonium nitrogen and total nitrogen ( \pm standard deviation) in estuary, shrimp pool effluents (SPE), control, treatment $\mathrm{T} 1$ and $\mathrm{T2}$. Different letters in the points means significant differences $(\mathbf{P}<\mathbf{0 . 0 5})$ / Nitrógeno amoniacal total y nitrógeno total ( \pm desviación estándar) en el estuario, efluentes de piscinas de camarón (SPE), control, tratamiento T1 y T2. Letras diferentes indican diferencias significativas $(P<0,05)$
Table 2. Means ( \pm standard deviation) of the survival (\%) of Chione fluctifraga in control and treatments, at days 0,48 and 77 of experiment / Supervivencia ( \pm desviación estándar) de Chione fluctifraga en control y tratamientos, en los días 0,48 y 77 del experimento

\begin{tabular}{ccccc}
\hline & \multicolumn{4}{c}{ Days of culture } \\
Density of clams & 0 & 48 & 77 & Statistical results \\
\hline T1 & $100^{\mathrm{a}}$ & $97 \pm 11^{\mathrm{a}}$ & $85 \pm 12^{\mathrm{a}}$ & $P<0.05$ \\
T2 & $100^{\mathrm{a}}$ & $87 \pm 9^{\mathrm{a}}$ & $69 \pm 9^{\mathrm{b}}$ & $P<0.05$ \\
\hline
\end{tabular}

The survival of clams in the treatments and in the estuary is presented in Table 2. Final survival was significantly higher in T1 (85\%) compared to T2 $\left(69 \%\right.$; $\mathrm{F}_{(1,4)}=3.9, P=$ $0.02)$. No differences were assessed regarding the condition index of the clams from T1 $(37.3 \pm 3.5 \%)$ and $\mathrm{T} 2(38.9 \pm$ $4.1 \%)$.

\section{Discussion}

The productive performance of shrimp into the pools was similar to previous reported performances in the semiintensive commercial farms, with a weekly growth around $1 \mathrm{~g}$ and a survival near to 70\% (Martínez-Córdova 1999); this suggests that the results of the present study may be applicable to the regional shrimp aquaculture.

The water quality of raw effluents was quite similar to that reported for intensive or semi-intensive shrimp farms. The levels of TSS found in shrimp effluents were within the range reported by Páez-Osuna (2001b) for intensive shrimp farms $\left(\mathrm{H} \approx 100\right.$ to $\left.350 \mathrm{mg} \mathrm{L}^{-1}\right)$. Also, similar values of suspended solids registered in the trial were observed by Jackson et al. (2004) in effluents discharged by different shrimp farms. The strong increase of TSS and OSS within the shrimp ponds during the culture could be related to the feed supplied and the sediment disturbance by the shrimp. These high levels of suspended solids represent a potential source of contamination either into the ponds or into effluent receiving ecosystems, as can occur in commercial farms (Biao \& Kaijin 2007).

In our study, the pools used as control and treatments simulated sedimentation lagoons and Chione fluctifraga was used as biofilter. Both strategies reduced the levels of suspended solids, but the reduction was more pronounced in the pools that contained clams. Martínez-Córdova \& Martínez-Porchas (2006) reported that the presence of $C$. fluctifraga in shrimp-culture ponds diminished the concentration of TSS, OSS and consequently improved the water quality. Other authors have reported that bivalves, e.g., Anadara grandis, A. tuberculosa, Crassostrea corteziensis 
and others, are capable to reduce the concentration of suspended solids (Miranda-Baeza et al. 2006, Wilber et al. 2006, Peña-Messina et al. 2009).

The decrease of TSS was more evident in the second part of the trial, possibly due an acclimation by the clams to the experimental conditions. Miranda-Baeza et al. (2006) documented that bivalves such as Anadara grandis can be acclimated to environments of high concentrations of suspended solids in few weeks.

The levels of OSS showed the same trend than the TSS, increasing form the estuary to the shrimp pools and then decreasing after passing through the treatments and the control pools. Therefore, the pools themselves contributed to the decrease of the OSS by sedimentation and the clams by biofiltration. It is well known that bivalves consume suspended particles (organic and inorganic) from the water column, retaining the organic fraction and discarding the inorganic (Troell \& Norberg 1998, Pfeiffer et al. 1999, Kasai $\&$ Nakata 2005). However, the inorganic fraction may also be decanted from seston by the filtration and discarding of bivalves (Ramos et al. 2009).

The amount of food supplied to the shrimp pools was adjusted weekly, and by the last day (77) the daily ration was 2-fold higher than the initial ration at day 0 . In spite of this, the concentrations of TSS and OSS decreased after passing through all the pools, instead of increasing, as one might expect; these results support the effectiveness of the treatments.

The total ammonia nitrogen increased in the shrimp pools, but decreased in the control and treatment pools. A significant portion of this reduction may be attributed to phytoplankton consumption. Although no measurement of chlorophyll or microalgae cells were made, it was evident from the colour of the water column that primary productivity was high during the trial; the lower TSS and OSS in the treatment pools may have improved the growth of phytoplankton and associated uptake of TAN. Newell et al. (2002) argued that Crassostrea virginica in shallow water may increase rates of denitrification. Bunting (2006) constructed an integrated shrimp-shellfish-seaweed polyculture system, reporting that the bivalve Scapharca inaequivalvis and the seaweed (Gracilaria spp.) reduced the concentrations of TAN, total nitrogen (TN) and total phosphorous (TP) from shrimp effluents by $61 \%, 72 \%$, and $71 \%$ respectively. Also, the pools themselves could contribute to the decrease of TAN; Ferrara \& Avci (1982) demonstrated that sedimentation pools or lagoons can reduce TAN by sedimentation and volatilization.
The observed reductions in levels of TAN, TSS, and OSS in the effluents, after flowing through the tanks would enhance the ability of shrimp farmers to recirculate the treated effluent or reduce impacts on receiving ecosystems. Despite the evident improvement in water quality of the effluents, only two densities of clams were evaluated, a

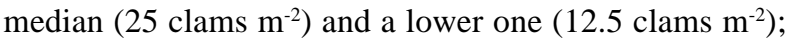
thus it is necessary to study more different densities in order to establish optimal and inflexion points.

The high survival of clams after the trial, suggests that the shrimp pond effluent may be an acceptable environment for the growth of the species, especially at the lower density used in this experiment $\left(12.5 \mathrm{~m}^{-2}\right)$ where a survival of $85 \%$ was observed; however, the use of sediment could provide a better environment for the thrive of clams and thus increase survival. Jakob et al. (1993) reported that effluents from shrimp ponds contained the necessary nutrients for the American oyster $C$. virginica to survive, though it is necessary to test production variables using juvenile organisms.

Also, the survival of clams in the experimental treatments was higher than that reported by Martinez-Cordova \& Martinez-Porchas (2006) in a polyculture system with shrimp. These results also suggest that there is the possibility to culture $C$. fluctifraga in shrimp effluent or even in shrimp ponds. Brzeski \& Newkirk (1997) argued that the polyculture of crustaceans with other mollusks decreased overall food requirements, cleaned pond effluents and in some cases, increased production and profit. Shipgel (2005) demonstrated that some bivalves (C. gigas and Tapes philippinarum) have potential as biofilters and as valuable by-products in land-based aquaculture. In a recent report it was documented that the shrimp farming industry in China uses bivalves to bioremediate effluents as a strategy to reduce the environmental impact (Biao \& Kaijin 2007).

The black clam Chione fluctifraga is a valuable source of food and it contributes to ecosystem health (MartínezCórdova 1988). The species may provide an interesting option to increase shrimp farm incomes and act as an effluent bioremediator. From the findings of this preliminary study we conclude that the effluent from shrimp ponds is an adequate environment in which $C$. fluctifraga can live, and adult organisms have a moderate capacity to bioremediate shrimp effluents. Also, the pools alone contributed to the decrease of suspended solids. Further studies are needed to evaluate other experimental designs and densities to determine the best combination for the biofiltration system. 


\section{ACKNowledgments}

This study was financially supported by Secretaría de Educación Pública de México (SEP-PROMEP).

\section{LITERATURE CITED}

Biao X \& Y Kaijin. 2007. Shrimp farming in China: Operating characteristics, environmental impact and perspectives. Ocean \& Coastal Management 50: 538-550.

Bower CE \& T Holm-Hansen. 1980. A salicylatehypochlorite method for determining ammonia in seawater. Canadian Journal of Fisheries and Aquatic Sciences 37: 794-798.

Brzeski V \& G Newkirk. 1997. Integrated coastal food production systems - a review of current literature. Ocean \& Coastal Management 34: 55-71.

Bunting SW. 2006. Low impact aquaculture. Centre for Environment and Society, University of Essex, Occasional Paper 2006-3: 1-32.

De la Hoz-Aristizábal MV. 2010. Condición somática de la almeja Polymesoda solida (Veneroidea: Corbiculidae) durante el periodo lluvioso, en el Parque Natural Isla de Salamanca, Caribe colombiano. Journal of Tropical Biology 58: 131-145.

FAO. 2008. FishStat Plus - Universal software for fishery statistical time series. Version 2.32. Fisheries and Aquaculture Department, FAO, Rome. [on line] <http:// www.fao.org/fishery/statistics/software/fishstat/en>

Ferrara RA \& CB Avci. 1982. Nitrogen dynamics in waste stabilization ponds. Journal of the Water Pollution Control Federation 54: 361-369.

Jackson C, N Preston \& PJ Thompson. 2004. Intake and discharge nutrient loads at three intensive shrimp farms. Aquaculture Research 35: 1053-1061.

Jakob GS, GD Pruder \& JK Wang. 1993. Growth trial the American oyster Crassostrea virginica using shirmp pond water as feed. Journal of the World Aquaculture Society 24: 344-351.

Jiménez-Casalduero F. 2001. Integrated systems: 'Environmentally clean' aquaculture. In: Uriarte A \& B Basurco (eds). Environmental impact assessment of Mediterranean aquaculture farms, pp. 139-145 CIHEAMIAMZ, Zaragoza. [on line] < http://ressources.ciheam.org/ om/pdf/c55/01600228.pdf>

Jones AB \& NP Preston. 2001. Sydney rock oyster Saccosstrea commercialis (Iredale y Roughley), filtration of shrimp farm effluent: the effects on water quality. Aquaculture Research 30: 51-57.

Jones AB, NP Preston \& WC Dennison. 2002. The efficiency and condition of oysters and macroalgae used as biological filters of shrimp pond effluent. Aquaculture Research 33: 1-19.
Kasai A \& A Nakata. 2005. Utilization of terrestrial oranic matter by the bivalve Corbicula japonica estimated from stable isotope analysis. Fisheries Science 71: 151-158.

Lefebvre S, L Barille \& M Clerc. 2000. Pacific oyster (Crassostrea gigas) feeding response to fish farm effluent. Aquaculture 187: 185-198.

Maples R, BW Nelson \& PG Verity. 1987. Lecture notes on coastal and estuarine studies. Book Review. Estuaries \& Coasts 10: 177-179.

Martínez-Córdova. LR. 1988. Bioecología de la almeja negra Chione fluctifraga (Sowerby, 1853). Revista de Biología Tropical 36: 213-219.

Martínez-Córdova. LR. 1999. Cultivo de camarones peneidos: Principios y prácticas, 283 pp. AGT Editor, México.

Martínez-Córdova LR \& M Martínez-Porchas. 2006. Polyculture of Pacific white shrimp Litopenaeus vannamei, giant oyster Crassostrea gigas and black clam Chione fluctifraga in ponds in Sonora, Mexico. Aquaculture 258: 321-326.

Martínez-Córdova LR, M Martínez-Porchas \& E CortésJacinto. 2009. Camaronicultura mexicana y mundial: ¿Actividad sustentable o industria contaminante? Revista Internacional de Contaminación Ambiental 25: 181-196.

Miranda-Baeza A, D Voltolina \& B Cordero-Ezquivel. 2006. Filtration and clearence rates of Anadara grandis juveniles (Pelecypoda, Aricidae) with different temperatures and suspended matter concentrations. Revista de Biología Tropical 54: 787-792.

Muangkeow B, K Ikejima, S Powtongsook \& Y Yi. 2007. Effects of white shrimp, Litopenaeus vannamei (Boone), and Nile tilapia, Oreochromis niloticus L., stocking density on growth, nutrient conversion rate and economic return in integrated closed recirculation system. Aquaculture 269: 363-376.

Neori A, M Troell, T Chopin, C Yarish, A Critchley \& AH Buschmann. 2007. The need for a balanced ecosystem approach to blue revolution aquaculture. Environment 49: 37-43.

Páez-Osuna F. 2001a. Eutroficación y camaronicultura. In: Osuna-Páez F (ed). Camaronicultura y medio ambiente, pp. 158-173. El Colegio de Sinaloa, UNAM, México.

Páez-Osuna F. 2001b. Impacto ambiental de la camaronicultura: Causas, efectos y alternativas de mitigación. In: Osuna-Páez F (ed). Camaronicultura y medio ambiente, pp. 412-424. El Colegio de Sinaloa, UNAM, México.

Peharda M, I Zupan, L Bavcevic, A Frankic \& T Klanjscek. 2007. Growth and condition index of mussel Mytilus galloprovincialis in experimental integrated aquaculture. Aquaculture Research 38: 1714-1720. 
Peña-Messina E, LR Martínez-Córdova, LF BückleRamírez, M Segovia-Quintero \& J Zertuche-González. 2009. A preliminary evaluation of physiological filtration variables for Crassostrea corteziensis (Hertlein, 1951) and Anadara tuberculosa (Sowerby, 1833) in shrimp aquaculture effluents. Aquaculture Research 40: 17501758.

Pfeiffer JT, BT Lawson \& AK Rusch. 1999. Northern quahog, Mercenaria mercenaria, seed clam waste characterization study: precursor to a recirculating culture system design. Aquaculture Engineering 20: 149-161.

Piedrahita RH. 2003. Reducing the potential environmental impact of tank aquaculture effluents through intensification and recirculation. Aquaculture 226: 35-44.

Primavera JH. 2006. Overcoming the impacts of aquaculture on the coastal zone. Ocean \& Coastal Management 49: 531-545.

Primavera JH, JP Altamirano, MJHL Lebata, A Reyes, A Delos \& CL Pitogo. 2007. Mangroves and shrimp pond culture effluents in Aklan, Panay Is., Central Philippines. Bulletin of Marine Science 80: 795-804.

Rahman MZ, A Reza, MSK Sarker, F Kabir \& MR Islam. 2002. Effect of shrimp culture on livestock feeds and fodder. Pakistani Journal of Biological Sciences 5: 980982.

Ramos R, L Vinatea, W Seiffert, E Beltrame, J SantosSilva \& RJ Ribeiro da Costa. 2009. Treatment of shrimp effluent by sedimentation and oyster filtration using Crassostrea gigas and C. rhizophorae. Brazilian Archives of Biology and Technology 52: 775-783.

Rawson MV Jr, C Chen, R Ji , M Zhu, D Wang, L Wang, C Yarish, JB Sullivan, T Chopin \& R Carmona. 2002. Understanding the interaction of extractive and fed aquaculture using ecosystem modeling. In: Stickney RR \& JP McVey (eds). Responsible marine aquaculture, pp. 263-296. CABI Publishing, Oxon.

Rivera-Monroy V, LA Torres, N Bahamon, F Newmark \& RR Twilley. 1999. The potential use of mangrove forest as nitrogen sinks of shrimp aquaculture pond effluents: the role of denitrification. Journal of the World Aquaculture Society 30: 12-25.
Sarà G. 2007. Ecological effects of aquaculture on living and non-living suspended fractions of the water column: A meta-analysis. Water Research 41: 3187-3200.

Shpigel M. 2005. Bivalves as biofilters and valuable byproducts in land-based aquaculture systems. In: Dame RF \& S Olenin (eds). The comparative roles of suspensionfeeders in ecosystems, pp. 183-197. Springer, Dordrecht.

Sousa OV, A Macrae, FGR Menezes, NCM Gomes, RHSF Vieira \& LCS Mendonça-Hagler. 2006. The impact of shrimp farming effluent on bacterial communities in mangrove waters, Ceará, Brazil. Marine Pollution Bulletin 52: $1725-1734$.

Tendencia EA. 2007. Polyculture of green mussels, brown mussels and oysters with shrimp control luminous bacterial disease in a simulated culture system. Aquaculture 272: 188-191.

Thu PM \& J Populus. 2007. Status and changes of mangrove forest in Mekong Delta: Case study in Tra Vinh, Vietnam. Estuarine, Coastal and Shelf Science 71: 98-109.

Tinoco-Orta GD \& J Cáceres-Martínez. 2003. Infestation of the clam Chione fluctifraga by the burrowing worm Polydora sp. nov. in laboratory conditions. Journal of Invertebrate Pathology 83: 196-205.

Troell M \& J Norberg. 1998. Modelling output and retention of suspended solids in an integrated salmon-mussel culture. Ecological Modelling 110: 65-77.

Troell M, C Halling, A Neori, T Chopin, AH Buschmann, N Kautsky \& C Yarish. 2003. Integrated mariculture: asking the right questions. Aquaculture 226: 69-90.

Wilber DH, DG Clarke \& MH Burlas. 2006. Suspended sediment concentrations associated with a beach nourishment project on the northern coast of New Jersey. Journal of Coastal Research 22: 1035-1042.

Yokoyama H, J Higano, K Adachi, Y Ishihi, Y Yamada \& P Pichitkul. 2002. Evaluation of shrimp polyculture system in Thailand based on stable carbon and nitrogen isotope ratios. Fisheries Science 68: 745-750.

Zar JH. 1996. Biostatistical analysis, 662 pp. Prentice-Hall, Englewood Cliffs.

Received 30 J une 2010 and accepted 18 March 2011 